\title{
Neuromuscular paralysis caused by an overdose of emepronium bromide (Cetiprin)
}

\author{
ANN FERGUSON AND DENISE A. BAKER \\ Department of Anaesthesia, Kent and Canterbury Hospital, Canterbury, Kent, England
}

\section{SUMMARY}

Emepronium bromide (Cetiprin) is an anticholinergic agent used therapeutically to reduce urinary frequency. We describe a voluntary overdose, which caused respiratory failure due to neuromuscular paralysis.

\section{CASE REPORT}

A 30-year-old woman with a history of depression developed puerperal depression treated with ECT and clomipramine. She was prescribed emepronium bromide for urinary tract symptoms and on the morning of admission took 100 tablets.

On admission to hospital she refused gastric lavage, was treated with ipecacuanha and returned some tablet residue identified as emepronium. On examination she had widely dilated pupils, a pulse of 130 and a normal body temperature. Four hours after ingestion she became intermittently confused and complained of difficulty in swallowing and breathing. Oxygen was administered by face-mask and blood gases showed a $\mathrm{pO}_{2}$ of $200 \mathrm{~mm} \mathrm{Hg}$ and a $\mathrm{pCO}_{2}$ of $55 \mathrm{~mm} \mathrm{Hg}$. She was moved to the intensive care unit where she rapidly became very distressed, making jerky limb movements and indicating her inability to breathe. She developed a bradycardia and was ventilated with $100 \%$ oxygen by face-mask and given external cardiac massage. Her pulse rate increased and she was intubated following administration of etomidate and suxamethonium. She was mechanically ventilated but continued making jerky limb movements similar to those made by a partially curarized patient, although no fade of train of four ratio could be seen using a peripheral nerve stimulator. She was sedated with midazolam but 
subsequently had good recall of these events, and complained particularly about severet limb weakness and inability to breathe.

Nine hours after the overdose she was able to breathe and move normally and was extubated.

She required a urinary catheter and her pupils remained dilated for a further 2 days.

\section{DISCUSSION}

Emepronium is a quaternary ammonium compound with some structural similarities to the non-depolarizing relaxants and therefore there is a theoretical possibility of neuromuscular blockade with high doses of emepronium. There have been no previous. reports of overdosage with emepronium and therefore it was assumed that symptoms. would be similar to overdosage with anticholinergic drugs, for example atropin (Martindale, 1982; Meyler, 1980). In addition, the regional poisons unit warned of possible difficulty with swallowing and speaking. This patient became more severel $\mathbb{N}$ paralysed, requiring 3 hours' respiratory support. According to the manufacturer (KabiVitrum) acute toxicity tests with emepronium in rats have shown respirator

impairment with pulmonary congestion at post-mortem.
At low plasma concentrations, emepronium does not enter the central nervous syster $\overrightarrow{\bar{c}}$ (Hansson \& Schmiterlow, 1961) but at high dosage sufficient may traverse the blood brain barrier to cause the confusion observed in this patient.

Although the serum half-life is short (1.5-2.25 hours) (Martindale, 1982; Sundwale êt al., 1973) it is excreted unchanged in the bile (Hansson \& Schmiterlow, 1961; Sundw et al., 1973) and reabsorption occurs, which may account for the length of time which this patient required a urinary catheter and had dilated pupils.

This case illustrates the difficulty of prescribing for patients with depression, and the assessment of patients following voluntary overdoses. Even well-known drugs, when taken in large overdoses, may produce unexpected side-effects, which may prove fatal

\section{ACKNOWLEDGEMENTS}

We would like to thank Dr D. J. E. Taylor for permission to publish this case, and Mrș E. Jeffries FPS and Mrs S. Corner for help with drug information.

\section{REFERENCES}

Hansson E. \& Schmiterlow C. G. (1961) Biological fate of $\mathrm{C}^{14}$ labelled Ethyl (3,3-diphenyl-1-methyl-propy (9) $^{\prime}$ dimethylammoniumbromide Cetiprin ${ }^{\mathrm{R}}$ a Monoquaternary Ammonium Compound. Acta Pharmacologic et Toxicologica 18, 183-90.

Martindale (1982) Extra Pharmacopeia. Pharmaceutical Press, London.

Meyler's Side-effect of Drugs (1980) Excerpta Medica. Amsterdam, Dukes.

Sundwall A., Vessman J. \& Strinberg B. (1973) Fate of emepronium in man in relation to its pharmacologic解 effects. European fournal of Clinical Pharmacology 6, 191-5. 